\title{
UNDERSTANDING RECENT TRENDS IN INCOME INEQUALITY IN THE PEOPLE'S REPUBLIC OF CHINA
}

Juzhong Zhuang and Li Shi

NO. 489

July 2016
ADB ECONOMICS WORKING PAPER SERIES 
ADB Economics Working Paper Series

\section{Understanding Recent Trends in Income Inequality in the People's Republic of China}

Juzhong Zhuang and Li Shi

No. 489 | July 2016
Juzhong Zhuang (jzhuang@adb.org) is deputy chief economist and deputy director general at the Economic Research and Regional Cooperation Department of the Asian Development Bank. Li Shi (lishi@bnu.edu.cn) is professor at Beijing Normal University.

The authors would like to thank Lea Sumulong and Damaris L. Yarcia for excellent research assistance. 
(C) 2016 Asian Development Bank

6 ADB Avenue, Mandaluyong City, 1550 Metro Manila, Philippines

Tel +632632 4444; Fax +6326362444

www.adb.org

Some rights reserved. Published in 2016.

Printed in the Philippines.

ISSN 2313-6537 (Print), 2313-6545 (e-ISSN)

Publication Stock No. WPS168253-2

Cataloging-In-Publication Data

Asian Development Bank.

Understanding recent trends in income inequality in the People's Republic of China.

Mandaluyong City, Philippines: Asian Development Bank, 2016.

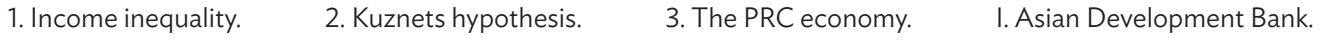

The views expressed in this publication are those of the authors and do not necessarily reflect the views and policies of the Asian Development Bank (ADB) or its Board of Governors or the governments they represent.

ADB does not guarantee the accuracy of the data included in this publication and accepts no responsibility for any consequence of their use. The mention of specific companies or products of manufacturers does not imply that they are endorsed or recommended by ADB in preference to others of a similar nature that are not mentioned.

By making any designation of or reference to a particular territory or geographic area, or by using the term "country" in this document, $A D B$ does not intend to make any judgments as to the legal or other status of any territory or area.

This work is available under the Creative Commons Attribution 3.0 IGO license (CC BY 3.0 IGO)

https://creativecommons.org/licenses/by/3.0/igo/. By using the content of this publication, you agree to be bound by the terms of this license.

This CC license does not apply to non-ADB copyright materials in this publication. If the material is attributed to another source, please contact the copyright owner or publisher of that source for permission to reproduce it. ADB cannot be held liable for any claims that arise as a result of your use of the material.

Attribution - In acknowledging ADB as the source, please be sure to include all of the following information:

Author. Year of publication. Title of the material. (c) Asian Development Bank [and/or Publisher].

URL. Available under a CC BY 3.0 IGO license.

Translations-Any translations you create should carry the following disclaimer:

Originally published by the Asian Development Bank in English under the title [title] (c) [Year of publication] Asian Development Bank. All rights reserved. The quality of this translation and its coherence with the original text is the sole responsibility of the [translator]. The English original of this work is the only official version.

Adaptations-Any adaptations you create should carry the following disclaimer:

This is an adaptation of an original Work (c) Asian Development Bank [Year]. The views expressed here are those of the authors and do not necessarily reflect the views and policies of ADB or its Board of Governors or the governments they represent. ADB does not endorse this work or guarantee the accuracy of the data included in this publication and accepts no responsibility for any consequence of their use.

Please contact publications@adb.org if you have questions or comments with respect to content, or if you wish to obtain copyright permission for your intended use that does not fall within these terms, or for permission to use the ADB logo.

Notes:

1. In this publication, "\$” refers to US dollars.

2. ADB recognizes "China" as the People's Republic of China.

3. Corrigenda to ADB publications may be found at: http://www.adb.org/publications/corrigenda 


\section{CONTENTS}

TABLES AND FIGURES $\quad$ iv

ABSTRACT $v$ v

$\begin{array}{ll}\text { I. INTRODUCTION } & 1\end{array}$

II. THE PEOPLE'S REPUBLIC OF CHINA'S INCOME INEQUALITY: 1978-2015

III. DRIVERS OF INCOME INEQUALITY: A CONCEPTUAL FRAMEWORK 4

IV. $\quad$ EMPIRICAL EVIDENCE

A. $\quad$ Skill Premium 6

B. Shares of Labor and Capital Incomes 8

C. Spatial Inequality 9

D. Wealth Distribution $\quad 12$

V. CONCLUSION: HAS THE PEOPLE'S REPUBLIC OF CHINA'S INCOME INEQUALITY PEAKED?

$\begin{array}{ll}\text { REFERENCES } & 15\end{array}$ 


\section{TABLES AND FIGURES}

\section{TABLES}

1 People's Republic of China's Gini Coefficients, 1978-2015

2 Pretax and Posttax Urban Gini Coefficient, People's Republic of China

\section{FIGURES}

$1 \quad$ Gini Coefficients, 1981-2015

2 Income Inequality Decomposition by Educational Attainment of Household Head, Selected Countries

3 Nominal Wage Growth of Low-Skill and High-Skill Sectors in the People's Republic of China, 2004-2014

$4 \quad$ Labor Income Share of Industry, Selected Developed Countries, 1980-2010 8

5 Shares of Labor and Capital Incomes in Manufacturing Value Added 9

6 Contribution of Spatial Inequality to Overall Inequality, Selected Asian Countries 10

$7 \quad$ Interhousehold Income Inequality Decomposition, Urban-Rural, 1990-2008 10

8 The Ratio of Urban-Rural per Capita Household Disposable Income, 1980-2015 11

$9 \quad$ Gini Coefficient of Provincial per Capita Incomes, 1990-2014 11

10 Gini Coefficient of per Capita Net Household Wealth, 1988-2012 12

11 Income Inequality in OECD Countries 


\begin{abstract}
This paper examines underlying factors that could explain the decline in income inequality in the People's Republic of China (PRC) since 2008 and inquires whether the decline indicates that the PRC's income inequality has peaked following the Kuznets hypothesis. The paper first identifies four key drivers of rising income inequality in the PRC since the mid-1980s: rising skill premium, declining share of labor income, increasing spatial inequality, and widening inequality in the distribution of wealth. It then provides evidence that the reversal of these drivers, with the exception of wealth inequality, could partly explain the decline in income inequality since 2008 . The paper argues that since part of the reversal of these drivers is policy induced, it is important that the policy actions continue for income inequality to decline further. The paper further argues that a critical factor underlying the Kuznets hypothesis is that taxation and transfers play a bigger role in income redistribution as a country becomes more developed, while their role is still limited in the PRC, the future path of the country's income inequality may not be one directional; and reducing income inequality significantly may require personal income tax and transfers to play a greater role over time.
\end{abstract}

Keywords: income inequality, Kuznets hypothesis, the PRC economy

JEL codes: D31, D63, N35 


\section{INTRODUCTION}

Rapidly rising income inequality in the People's Republic of China (PRC) since economic reform started in the late 1970s has attracted considerable attention by policy makers and researchers in and outside the country in recent years ( $\mathrm{Li}, \mathrm{Wan}$, and Zhuang 2014). While the Chinese economy has managed to grow at close to $10 \%$ annually for more than 3 decades, and the growth has helped lift hundreds of millions of people out of poverty, the Chinese society has in the process become less equal. The Gini coefficient of per capita household disposable income was below 30 in the early 1980s (Ravallion and Chen 2007).' In 2015, according to the estimate of China National Bureau of Statistics (CNBS), it stood at 46.2 (CNBS 2016). This is a high level compared with many countries in Asia (ADB 2012).

However, in more recent years, the PRC's Gini coefficient has been on the decline. According to the estimates released by CNBS in recent years, the Gini coefficient reached a peak at 49.1 in 2008, fell to 48.1 in 2010, 47.7 in 2011, 47.4 in 2012, 47.3 in 2013, 46.9 in 2014, and 46.2 in 2015 (Wan and Zhuang 2015; CNBS 2015, 2016). These declines have led some to ask whether the PRC's income inequality has peaked, and whether this vindicates the Kuznets hypothesis which says that a country's income inequality tends to increase at an early stage of development, and peak and then decline when the income increases to a certain level. ${ }^{2}$

The purpose of this paper is to examine the underlying factors that could explain the recent decline in the PRC's Gini coefficient and ask whether the decline indicates that the income inequality has peaked. To answer this question, in section II, the paper provides a brief review of the evolution of income inequality in the PRC during the period 1978-2015. Section III constructs a simple conceptual framework where key drivers of income inequality can be analyzed. Section IV presents empirical evidence on the key drivers and discusses their relevance to explaining the dynamics of inequality in the PRC in the last 3-4 decades, including the recent decline. Section $\vee$ concludes.

\section{THE PEOPLE'S REPUBLIC OF CHINA'S INCOME INEQUALITY: 1978-2015}

This section pieces together a broad picture of the evolution of income inequality in the PRC during 1978-2015 using estimates of the Gini coefficient from various sources. Largely due to the public unavailability of household survey data covering the entire country, earlier attempts to assess the level of income inequality in the PRC focused on the measurement of regional or interhousehold inequality in specific locations, such as rural or urban areas, and in specific provinces for specific periods (see Tsui 1993, Rozelle 1994, Hussain and Zhuang 2000, Kanbur and Zhang 1999). More recently, attempts to measure income inequality have also used synthetic unit-level data generated from grouped household income and consumption expenditure data covering most provinces (Lin et al. 2010).

Inequality can be measured using per capita income or consumption expenditure. Inequality measured by the former is usually higher, in the case of the Gini coefficient, by 5-10 points when measured using the range of 0-100 (ADB 2012). Unless otherwise noted, this paper focuses on income-based inequality. Table 1 presents eight sets of estimates of the Gini coefficient of per capita

\footnotetext{
The Gini coefficient of per capita household income (or consumption) is a commonly used measure of income inequality, and it ranges from 0 indicating perfect equality to 100 (or 1 ) indicating perfect inequality.

2 Questions have also been raised over the quality of statistical data in the PRC.
} 
household income in the PRC in the postreform period, although two sets present problems and will not be used further here. ${ }^{3}$

Table 1: The People's Republic of China's Gini Coefficients, 1978-2015

\begin{tabular}{|c|c|c|c|c|c|c|c|c|}
\hline \multirow[b]{2}{*}{ Year } & \multirow[b]{2}{*}{$\begin{array}{l}\text { World } \\
\text { Development } \\
\text { Indicators }^{\mathrm{a}}\end{array}$} & \multicolumn{2}{|c|}{ Ravallion and Chen (2007) } & \multirow[b]{2}{*}{ WIID } & \multirow[b]{2}{*}{$\begin{array}{l}\text { Chinese } \\
\text { Household } \\
\text { Income }^{\text {Comect }}\end{array}$} & \multicolumn{2}{|c|}{ Lin et al. (2010) } & \multirow[b]{2}{*}{$\begin{array}{c}\text { National } \\
\text { Bureau of } \\
\text { Statistics } \\
\text { (NBS) }\end{array}$} \\
\hline & & $\begin{array}{c}\text { Without } \\
\text { Adjustment } \\
\text { for Spatial } \\
\text { COL } \\
\text { Difference }\end{array}$ & $\begin{array}{c}\text { With } \\
\text { Adjustment } \\
\text { for Spatial } \\
\text { COL } \\
\text { Difference }\end{array}$ & & & $\begin{array}{c}\text { Without } \\
\text { Adjustment } \\
\text { for Spatial } \\
\text { COL } \\
\text { Difference }\end{array}$ & $\begin{array}{c}\text { With } \\
\text { Adjustment } \\
\text { for Spatial } \\
\text { COL } \\
\text { Difference }\end{array}$ & \\
\hline 1978 & $\ldots$ & $\ldots$ & $\ldots$ & 31.7 & $\ldots$ & $\ldots$ & $\ldots$ & $\ldots$ \\
\hline 1979 & $\ldots$ & $\ldots$ & $\ldots$ & $\ldots$ & $\ldots$ & $\ldots$ & $\ldots$ & $\ldots$ \\
\hline 1980 & $\ldots$ & $\ldots$ & $\ldots$ & $\ldots$ & $\ldots$ & $\ldots$ & $\ldots$ & $\ldots$ \\
\hline 1981 & 29.1 & 31.0 & 28.0 & $\ldots$ & $\ldots$ & $\ldots$ & $\ldots$ & $\ldots$ \\
\hline 1982 & $\ldots$ & 28.5 & 25.9 & $\ldots$ & $\ldots$ & $\ldots$ & $\ldots$ & $\ldots$ \\
\hline 1983 & $\ldots$ & 28.3 & 26.0 & 28.4 & $\ldots$ & $\ldots$ & $\ldots$ & $\ldots$ \\
\hline 1984 & 27.7 & 29.1 & 26.9 & $\ldots$ & $\ldots$ & $\ldots$ & $\ldots$ & $\ldots$ \\
\hline 1985 & $\ldots$ & 29.0 & 26.5 & 22.4 & $\ldots$ & $\ldots$ & $\ldots$ & $\ldots$ \\
\hline 1986 & $\ldots$ & 32.4 & 29.2 & $\ldots$ & $\ldots$ & $\ldots$ & $\ldots$ & $\ldots$ \\
\hline 1987 & 29.9 & 32.4 & 28.9 & $\ldots$ & $\ldots$ & $\ldots$ & $\ldots$ & $\ldots$ \\
\hline 1988 & $\ldots$ & 33.0 & 29.5 & 38.2 & 39.5 & $\ldots$ & $\ldots$ & $\ldots$ \\
\hline 1989 & $\ldots$ & 35.2 & 31.8 & $\ldots$ & $\ldots$ & $\ldots$ & $\ldots$ & $\ldots$ \\
\hline 1990 & 32.4 & 34.9 & 31.6 & $\ldots$ & $\ldots$ & 34.5 & 28.7 & $\ldots$ \\
\hline 1991 & $\ldots$ & 37.1 & 33.1 & 34.1 & $\ldots$ & $\ldots$ & $\ldots$ & $\ldots$ \\
\hline 1992 & $\ldots$ & 39.0 & 34.2 & $\ldots$ & $\ldots$ & $\ldots$ & $\ldots$ & $\ldots$ \\
\hline 1993 & 35.5 & 42.0 & 36.7 & $\ldots$ & $\ldots$ & $\ldots$ & $\ldots$ & $\ldots$ \\
\hline 1994 & $\ldots$ & 43.3 & 37.6 & $\ldots$ & $\ldots$ & $\ldots$ & $\ldots$ & $\ldots$ \\
\hline 1995 & $\ldots$ & 41.5 & 36.5 & 29.0 & 46.9 & 39.7 & 32.9 & $\ldots$ \\
\hline 1996 & 35.7 & 39.8 & 35.1 & 39.0 & $\ldots$ & $\ldots$ & $\ldots$ & $\ldots$ \\
\hline 1997 & $\ldots$ & 39.8 & 35.0 & $\ldots$ & $\ldots$ & $\ldots$ & $\ldots$ & $\ldots$ \\
\hline 1998 & $\ldots$ & 40.3 & 35.4 & $\ldots$ & $\ldots$ & $\ldots$ & $\ldots$ & $\ldots$ \\
\hline 1999 & 39.2 & 41.6 & 36.4 & $\ldots$ & $\ldots$ & $\ldots$ & $\ldots$ & $\ldots$ \\
\hline 2000 & $\ldots$ & 43.8 & 38.5 & 39.0 & $\ldots$ & 41.1 & 34.7 & $\ldots$ \\
\hline 2001 & $\ldots$ & 44.7 & 39.5 & $\ldots$ & $\ldots$ & $\ldots$ & $\ldots$ & $\ldots$ \\
\hline 2002 & 42.6 & $\ldots$ & $\ldots$ & 45.4 & 46.8 & $\ldots$ & $\ldots$ & $\ldots$ \\
\hline 2003 & $\ldots$ & $\ldots$ & $\ldots$ & 44.9 & $\ldots$ & $\ldots$ & $\ldots$ & 47.9 \\
\hline 2004 & $\ldots$ & $\ldots$ & $\ldots$ & $\ldots$ & $\ldots$ & $\ldots$ & $\ldots$ & 47.3 \\
\hline 2005 & 42.5 & $\ldots$ & $\ldots$ & $\ldots$ & $\ldots$ & 45.7 & 38.8 & 48.5 \\
\hline 2006 & $\ldots$ & $\ldots$ & $\ldots$ & $\ldots$ & $\ldots$ & $\ldots$ & $\ldots$ & 48.7 \\
\hline 2007 & $\ldots$ & $\ldots$ & $\ldots$ & $\ldots$ & 49.7 & $\ldots$ & $\ldots$ & 48.4 \\
\hline 2008 & 42.6 & $\ldots$ & $\ldots$ & $\ldots$ & $\ldots$ & $\ldots$ & $\ldots$ & 49.1 \\
\hline 2009 & $\ldots$ & $\ldots$ & $\ldots$ & $\ldots$ & $\ldots$ & $\ldots$ & $\ldots$ & 49.0 \\
\hline 2010 & 42.1 & $\ldots$ & $\ldots$ & $\ldots$ & $\ldots$ & $\ldots$ & $\ldots$ & 48.1 \\
\hline 2011 & $\ldots$ & $\ldots$ & $\ldots$ & $\ldots$ & $\ldots$ & $\ldots$ & $\ldots$ & 47.7 \\
\hline 2012 & $\ldots$ & $\ldots$ & $\ldots$ & $\ldots$ & $\ldots$ & $\ldots$ & $\ldots$ & 47.4 \\
\hline 2013 & & & & & & & & 47.3 \\
\hline 2014 & & & & & & & & 46.9 \\
\hline 2015 & & & & & & & & 46.2 \\
\hline
\end{tabular}

$\ldots=$ data not available, $\mathrm{COL}=$ cost of living, $\mathrm{WIID}=$ World Income Inequality Database.

a Based on income (1981-1987) and consumption (1990-2009).

b A project of Beijing Normal University.

Sources: Wan and Zhuang 2015; CNBS 2015, 2016.

3 The World Income Inequality Database set was collected from different publications and may be based on different datasets, which could explain why they vary considerably from one year to another. The Gini indexes from the World Development Indicators (WDI) database are inconsistent because post-1989 estimates are consumption based, while the earlier estimates are income based. Further, WDI estimates could be biased as they are weighted averages of rural and urban estimates, and do not consider disparities between rural and urban average income or consumption, which have been substantial. 
Among the remaining six sets of estimates, two were obtained by adjusting for spatial cost of living (COL) differences. If one compares the spatial COL-adjusted estimates with the corresponding unadjusted estimates, the latter are much larger (by 15\%-30\%). Since most researchers do not consider spatial COL differences, we will ignore the two sets of adjusted estimates. However, the adjusted and unadjusted estimates share the same trends.

Figure 1 plots estimates from the remaining four sources. These are comparable and all show a rising trend of income inequality. ${ }^{4}$ In particular, the Ravallion and Chen (2007) estimates show that income inequality declined at the onset of economic reform until the mid-1980s-due largely to rising rural incomes following the rural economic reforms, including the introduction of household responsibility system - and since then it has been on the rise amid some fluctuations.

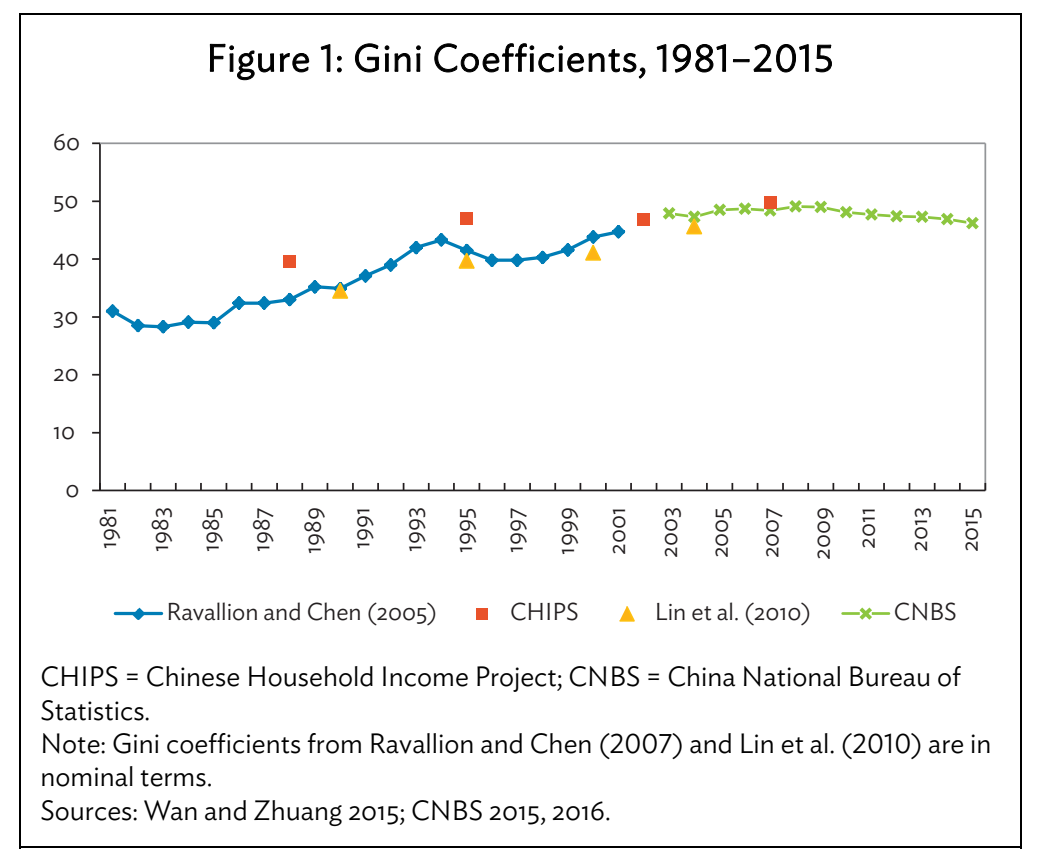

Estimates by CNBS-for recent years - show a more stable trend. Inequality peaked in 2008, with a Gini estimate of 49.1, and has since been on the decline, though marginally, each year, reaching its lowest recent level at 46.2 in 2015. One can combine the CNBS estimates with those of Ravallion and Chen (2007) to form a more complete time series on the PRC's income inequality. This shows that, over a period of 35 years, inequality as measured by the Gini coefficient grew by more than $50 \%$ from 28.3 in 1983 to 49.1 in 2008, and then dipped to 46.2 in 2015. Whether the recent decline represents the beginning of the end of worsening income distribution in the PRC-as suggested by the Kuznets hypothesis - is still a debated issue.

4 Ravallion and Chen (2007) used data directly provided by the CNBS, while Lin et al. (2010) used CNBS data in grouped form. The Chinese Household Income Project (CHIP) data are piggybacked by a CNBS survey. It is clear that the CHIP data estimates are consistently larger and Lin et al. (2010) consistently smaller than all the other estimates. The discrepancies can be attributed to the approximation method Lin et al. (2010) used to obtain unit-record data from grouped data. The CHIP data have a smaller coverage in sample size than the data used by others. 


\section{DRIVERS OF INCOME INEQUALITY: A CONCEPTUAL FRAMEWORK}

This section presents a simple framework to look at drivers of income inequality, extending ADB (2012). The framework is based on the definition of total income of a household, $Y$, as the sum of its income derived from labor and that derived from capital (or wealth):

$$
Y=W L+R K
$$

Capital income is the product of the different types of capital assets $(K)$ owned by the household and their respective rates of return $(R)$. For a typical household, capital assets consist mostly of housing, land, factories and machinery owned by households, and financial assets. ${ }^{5}$ Labor income-which includes returns to human capital-is the product of the different types of labor assets $(L)$ and their respective wage rates $(W)$. The return to human capital is reflected in the skill premium, that is, the more educated and skilled labor earns higher wages.

Income inequality estimates, such as the Gini coefficient, are often based on per capita household income, that is:

$$
\frac{Y}{H}=W\left(\frac{L}{H}\right)+R\left(\frac{K}{H}\right)
$$

Therefore, inequality in per capita household income is the result of inequality in per capita labor income $(W L / H)$, inequality in per capita capital income $(R K / H)$, and the relative importance of labor and capital incomes in total household income. ${ }^{6}$ Changes in income inequality can be thought of as resulting from a combination of changes in the distributions of per capita labor assets and capital assets across households, changes in the relative returns to labor and capital, and changes in the relative importance of labor and capital incomes in total household income.

In any society, the distribution of capital assets reflects its ownership structure, while the distribution of labor assets is determined to a large extent by the inequality in access to education and health. Over time, many factors shape these distributions, including initial distributions, household savings behavior and investment decisions, differences in individual efforts and entrepreneurship, political economy factors (such as pressures for land redistribution, taxation on labor and capital incomes, and public spending on human capital), the quality of governance and institutions, and demographics.

Changes in the relative returns to labor and capital reflect demand and supply conditions in the marketplace, how efficiently the market works - for instance, the presence or absence of monopoly or discrimination against particular population groups (such as females or rural residents), and political economy factors (such as labor market institutions and taxation on labor and capital incomes).

Finally, changes in the relative importance of labor and capital incomes in total household income are determined by the relative changes in returns to labor and capital and in the capital-labor

5 In this paper we use the terms "capital" and "wealth" interchangeably. Capital includes all real and financial assets owned by a household, but excludes human capital. A household's capital incomes include all the incomes from owning various capital assets. See discussions in Piketty (2014, 36-38).

6 Lerman and Yitzhaki (1985) decompose the Gini coefficient into the contributions by income source. Each source's contribution to overall inequality is the product of its own Gini coefficient, its share in total income, and its correlation with the rank of total income. 
ratio in production. These are in turn determined by technological advances and the bias of technical progress; the relative bargaining positions of labor and capital; political economy factors such as labor market institutions (minimum wages, collective bargaining, and employment protection); taxation; and the presence or absence of market distortions.

Within this framework, income inequality will increase if changes in relative returns to labor and to capital, or in the distribution of labor assets and capital assets, or in the relative importance of labor and capital incomes in total income favor the better-off households. There are many ways in which this could happen.

First, wage rates could increase faster for the better educated and skilled workers than for the less educated and skilled. There is a large literature showing that globalization and technological progress may have increased the demand for skilled workers relative to that for unskilled workers in many developing countries, leading to an increasing skill premium (ADB 2012). In the case of the PRC, the market-oriented reforms introduced since the late 1970s dismantled the fixed-wage system that existed under central planning, and have made wages more reflective of workers' skills and educational attainments and of market demand and supply conditions, and have also contributed to the increase in the skill premium, as evidenced by rising wage inequality (Knight and Song 2003, Deng and Li 2009).

Second, the differentials in the returns to capital and in wage rates between Chinese richer coastal and urban areas and the poorer interior and rural areas could increase as growth accelerated, leading to increasing spatial inequality. This is because coastal regions are closer to trade routes and world markets than interior regions; and because urban cities have better infrastructure than rural areas, they are more likely to attract investment and new technologies, especially during the initial phase of growth takeoff (Lewis 1954). All these could lead to greater increases in productivity, wages and returns to capital in the favored areas. Land and housing prices have increased much faster in coastal areas and urban cities than in inland provinces and rural areas in the PRC in the last 40 years or so.

Third, capital income could increase faster than labor income. This would lead to a rising share of capital income in total household income (which tends to be less equally distributed) and a declining share of labor income (which tends to be more equally distributed). This occurs when total income grows faster than labor income (or when per capita income grows faster than the wage rate), leaving a larger share of value added accruing to capital. It has been suggested that technological progress especially in information and communications technology and automation may have reduced the demand for labor relative to that for capital, as shown by a declining employment elasticity of growth in recent decades in many countries, thus favoring capital (ADB 2012). In the case of the PRC, the large pool of rural surplus labor has also put downward pressure on wage rates until recently (Knight, Deng, and Li 2011).

Fourth, increasing inequality in the distribution of human capital (embedded in labor) or capital (or wealth) can also lead to an increase in income inequality. Inequality in human capital could increase if wealthier households invest more on or have better access to education and health than poorer households. Inequality in wealth could increase if wealthier households save more, if they receive higher returns to capital due to economies of scale or if they have lower fertility rates than less-wealthy households. 


\section{EMPIRICAL EVIDENCE}

This section provides empirical evidence on the major drivers of rising income inequality in the PRC in recent decades, focusing on skill premium, share of capital income in national income, spatial inequality, and wealth distribution. Although distribution of human capital is also highly relevant in our framework, due to the lack of data, it is not included in the empirical analysis below.

\section{A. Skill Premium}

In many countries, wage inequality is often a major contributor to inequality of income. In Asia, empirical studies find that returns to education increase with educational attainment and that the relationship has been getting stronger over time in recent years. An ADB study finds that from the mid1990s to the mid-2000s, real wages grew much faster for wage earners with tertiary or higher education than for those with lower educational attainment in India and the Philippines, leading to wider wage differentials (Zhuang, Kanbur, and Rhee 2014). In India, the Gini coefficient of wages increased from 40.5 in 1993 to 47.2 in 2004 and about 50\% of the increases was accounted for by education. Many studies provide direct evidence of rising skill and education premiums in Asia (World Bank 2012).

Returns to education have also risen in the PRC in the postreform period (Zhang et al. 2005, Liu 2009). The World Bank (2012) estimates that the tertiary education premium was 60\% in 2005 and increased across sectors in recent years. Household survey data show the growing importance of educational status in explaining interhousehold income inequality. Sicular et al. (2008) find that education can explain more than 25\% of the PRC's urban-rural income gap. The ADB (2012) finds that, based on survey data, the share of income inequality accounted for by differences in educational attainment of heads of households increased from 8.1\% in 1995 to 26.5\% in 2007 (Figure 2). The study also finds that the importance of education in explaining household incomes has risen in many other Asian countries as well, such as Bhutan, India, Pakistan, the Philippines, and Thailand. However, the increase was most pronounced in the PRC.

More recent empirical evidence, however, suggests that the increase in skill premium may have slowed down or the level of skill premium may have decreased in the PRC. Assuming that the wage levels above the national average correspond to jobs requiring high skills, and that those below the national average correspond to jobs requiring low skills, recent data show that wages in high-skill sectors are now rising at a slower pace than wages in low-skill sectors (Figure 3). During 2004-2009, with the exception of 2008, the average wage growth was faster for high-skill sectors than low-skill sectors. Since 2009, however, the average wage growth has been faster for low-skill sectors than for high-skill sectors. In 2011, for example, the average wage growth for low-skill sectors was close to 20\%, while that for high-skill sectors was only about $14 \%$. 
Figure 2: Income Inequality Decomposition by Educational Attainment of Household Head, Selected Countries

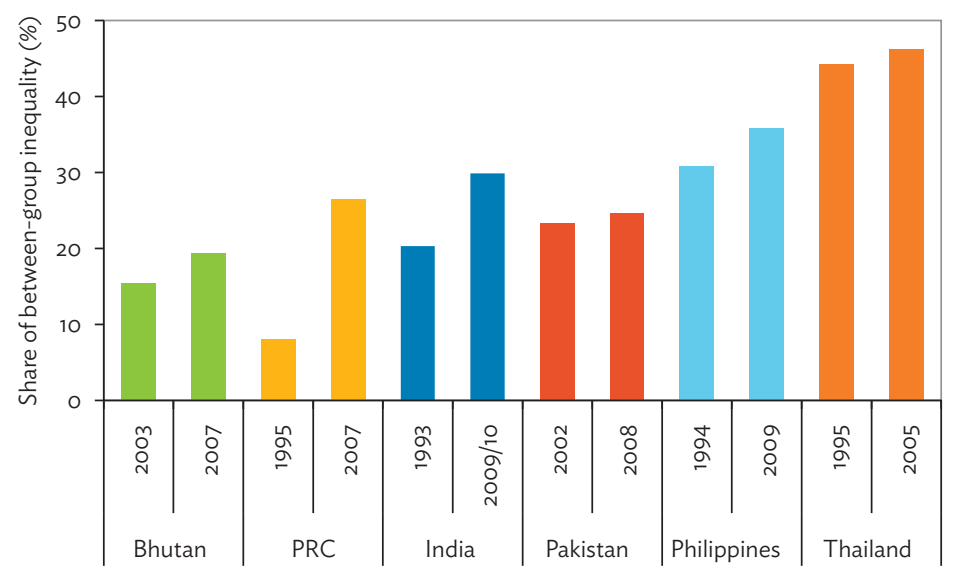

PRC $=$ People's Republic of China.

Note: Estimates are based on per capita consumption expenditure in nominal terms except for the PRC, which is based on income. The decomposition is based on $\mathrm{GE}(0)$, which is a special form of the generalized entropy index.

Source: Asian Development Bank 2012.

\section{Figure 3: Nominal Wage Growth of Low-Skill and High- Skill Sectors in the People's Republic of China, 2004-2014}

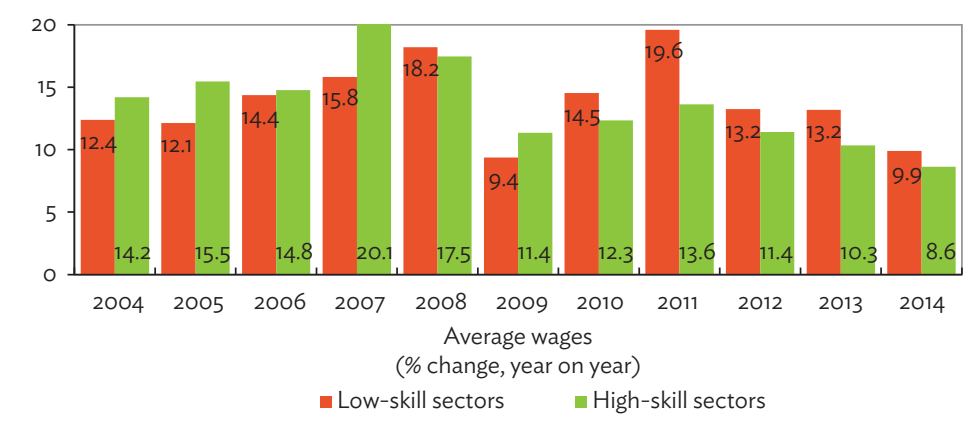

Notes:

1. Low-skill sectors: agriculture, forestry, animal husbandry, and fishery; manufacturing; construction; wholesale and retail trades; hotels and catering services; management of water conservancy, environment, and public facilities; services to households, repair, and other services.

2. High-skill sectors: mining; production and supply of electricity, heat, gas, and water; transport, storage, and post; information transmission, software, and information technology; financial intermediation; real estate; leasing and business services; scientific research and technical services; education; health and social service; culture, sports, and entertainment; public management, social security, and social organization.

Source: China National Bureau of Statistics. http://www.stats.gov.cn/english/ (accessed 16 April 2016). 
One possible reason for the declining skill premium in the PRC in recent years is a rapid increase in the investment in tertiary education. The annual university enrollment increased from 0.93 million in 1995 to 6.62 million in 2010, and it has been reported that many university graduates find it difficult to find suitable jobs in recent years, leading to high unemployment among these graduates (Chan 2015; Knight, Deng, and Li 2016). This may have put downward pressures on wage rates for the better-educated labor. Another possible reason is rapid increases in the minimum wage rates ( $\mathrm{Li}$ and Lin 2015). During 2010-2014, the average monthly minimum wage rate in coastal provinces, applicable mostly to low-skilled workers, grew by $56.2 \%$, and the average wage rate of the urban nonprivate sector, applicable mostly to high-skilled workers, grew only by $54.2 \%$ (CNBS, China Statistical Yearbook).

\section{B. Shares of Labor and Capital Incomes}

A decline in the share of labor income (with the consequent increase in the share of capital income) in national income can increase income inequality because, in general, labor income is more equally distributed than capital income. During the last 2 decades, many countries, both developed and developing, saw the income share of labor fall. In the United States, this share declined from 65\% in 1992 to 52.4\% in 2009 in industry (Figure 4), and, for the entire economy and during the same period, it fell from $68.7 \%$ to $64.2 \%$. In Germany, the share increased from the mid-1980s until 1993, when it peaked at $79.5 \%$, but has declined since then.

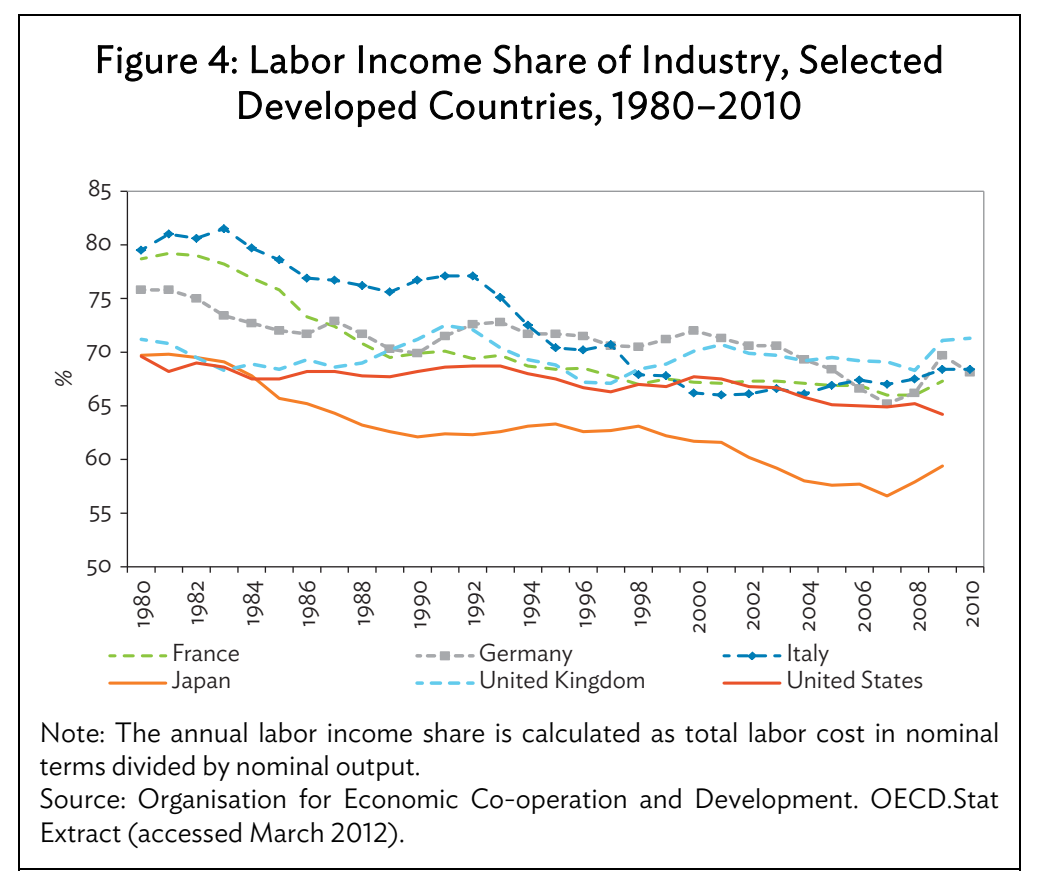

In the PRC, Bai and Qian (2009) find that the share of labor income in the manufacturing sector fell from $48.4 \%$ in the mid-1990s to $42.2 \%$ in the mid-2000s. An ADB study (2012) shows that many other Asian economies also experienced a falling share of labor income, including India; Indonesia; Japan; the Republic of Korea; Singapore; and Taipei,China. However, more recent data suggests that the share of labor income in the PRC's manufacturing sector has started rising, from $46.4 \%$ in 2005 to $53.9 \%$ in 2010, and 55.3\% in 2012 (Figure 5). 


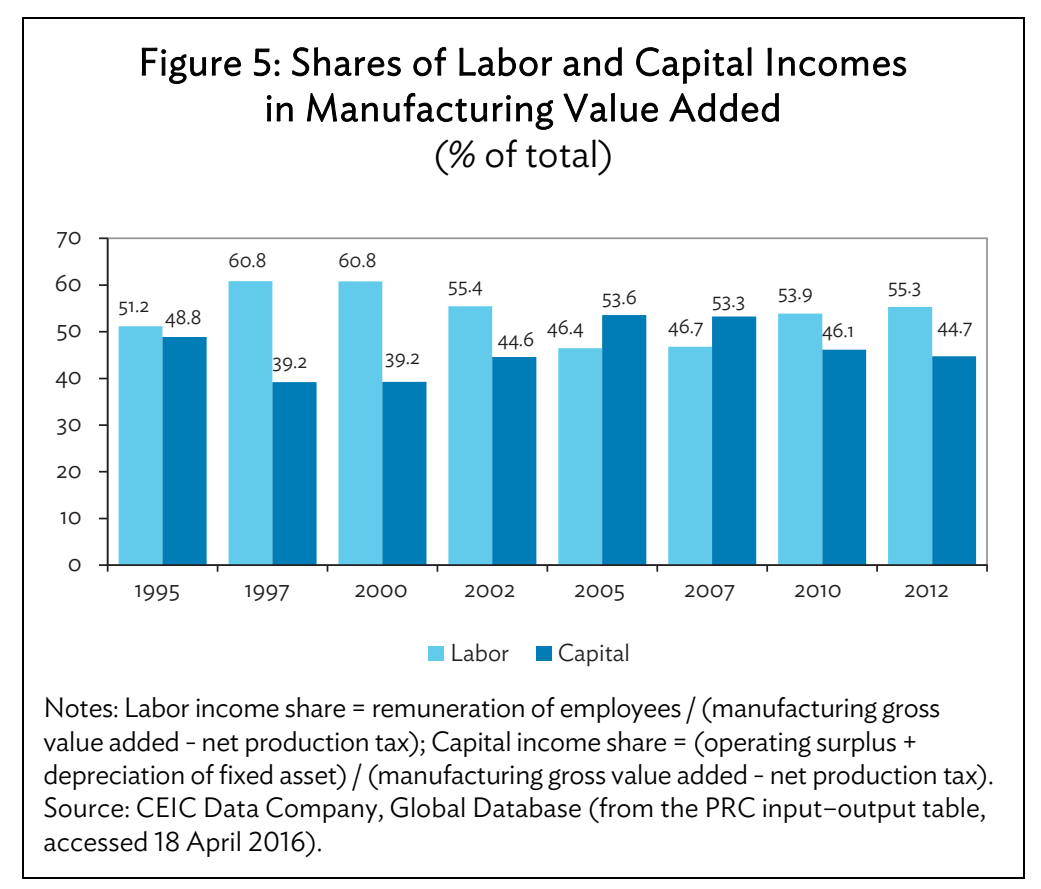

Many have argued that the PRC is approaching the so-called "Lewis turning point" where the pool of rural surplus labor has shrunk to the extent that further rural migration to cities would require greater wage increases, leading to labor market tightening in urban areas. This is consistent with the fact that Chinese coastal provinces have been experiencing labor shortages since the mid-2000s (ADB 2012). However, it has also been noted that the increase in the labor income share was partly due to redefining labor income share by the CNBS; some implicit subsidies and government spending on welfare programs have now been reclassified as a part of labor income, which was not in the previous statistics (Li, Wan, and Zhuang 2014).

\section{Spatial Inequality}

Increasing spatial inequality, covering both urban-rural income gaps and interprovincial disparities, has been particularly important as a channel by which technological progress, integration with the global economy, and market-oriented reform impact income distribution in the PRC. Just as the distribution of economic activity is structured geographically, so is the distribution of income. Some locations have natural advantages, such as fertile soil for agriculture or proximity to a coastline for trade or better infrastructure in cities. Economic analysis has also highlighted the role of agglomeration benefits (Krugman 2008). According to an ADB study (2012), in 2007, more than $50 \%$ of income inequality in the PRC can be explained by the spatial inequality, the highest among Asian countries with comparative data (Figure 6).

The increasing urban-rural income gap is a particularly significant contributor to rising inequality in the PRC. Using synthetic unit-level data estimated from the grouped household income and consumption expenditure data covering $85 \%$ of the population and updating estimates of Lin et al. (2010), it is found that the share of between-urban-rural inequality in total income inequality increased from about 20\% in 1990 to 32\% in 2008 after adjusting household income by differences in the cost of living between urban and rural areas (Figure 7). During the same period, the share of withinrural inequality declined from $66 \%$ to $32 \%$ and that of within-urban inequality increased from $14 \%$ to $37 \%$. Without adjusting household income by cost of living differences, ADB (2012) finds that the 
share of the between-urban-rural inequality increased from 34\% in 1990 to $45 \%$ in 2008. The ADB study (2012) shows that the PRC is not the only country in Asia that experienced rising urban-rural income gaps in the last 2 decades.

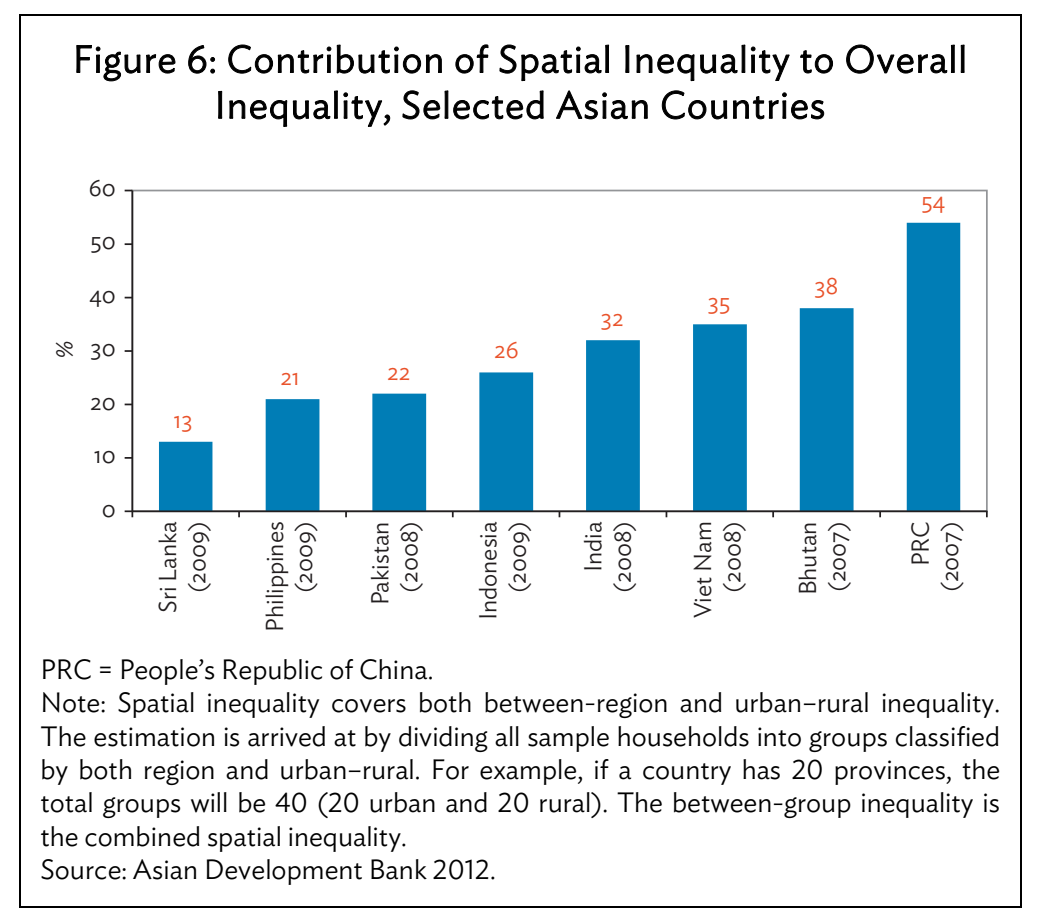

However, recent data suggest that urban-rural income gap in the PRC has started decline in recent years. The urban-rural ratio of the mean per capita household disposable income was on the rise consistently from the mid-1990s to mid-2000s. But it has been on the decline more recently, from 3.33 in 2007 to 2.9 in 2015 (Figure 8). Despite statistical issues related to these figures that have often been raised (such as the definition of rural and urban households and the treatment of rural migrants), the trend shows a consistent decrease in the ratio in recent years.

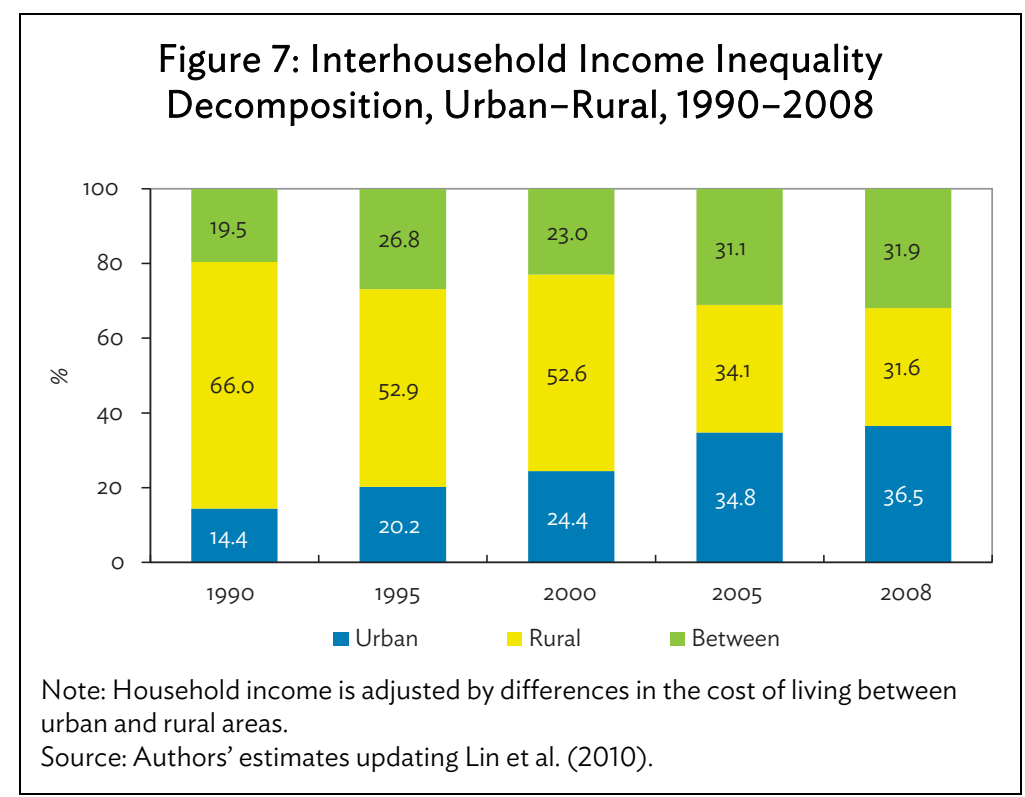


A number of factors could explain this decline in urban-rural income gap. Large migration from rural to urban areas reduces rural surplus labor and helps improve labor productivity of farming. Rapid pace of urbanization also helps reduce urban-rural income gaps. Recent government policy actions in supporting rural peasants (such as investment in rural infrastructure, improvement in social security, and antipoverty programs) have also contributed to increasing rural income and declining urban-rural income gaps (Li, Sato, and Sicular 2013).

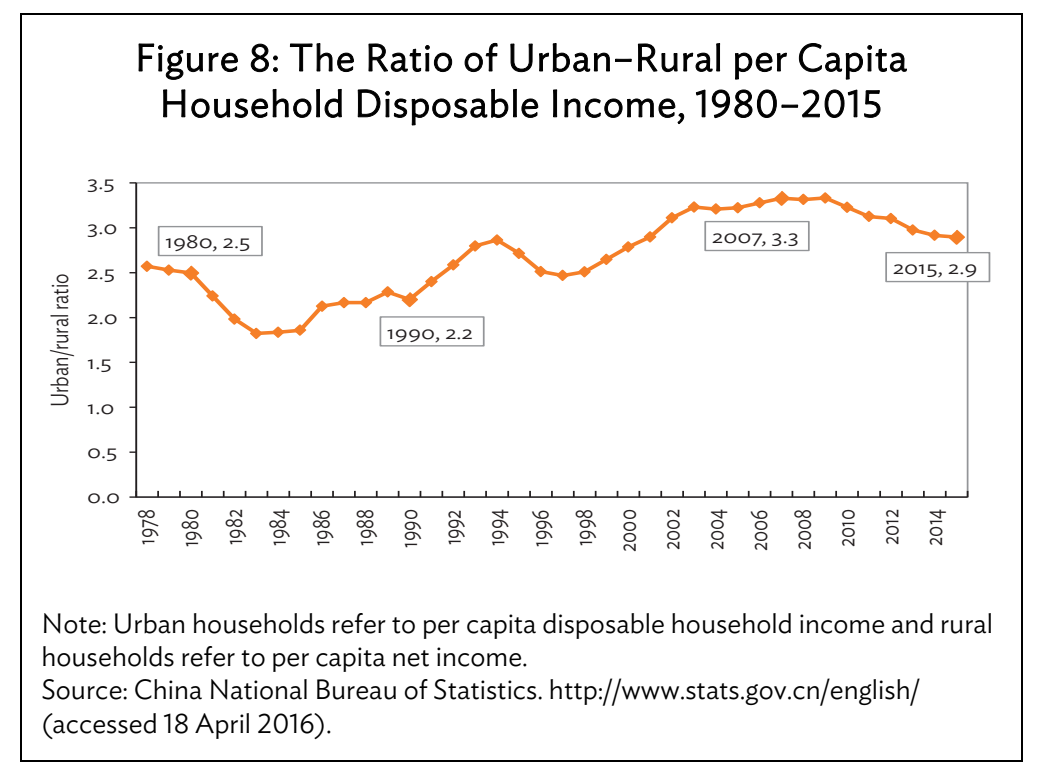

The other dimension of spatial inequality is regional inequality, which has also been a key contributor to rising inequality in the PRC. During 1990-2003, the Gini coefficient of per capita provincial income increased more or less concurrently with the overall national Gini coefficient. However, since 2003, regional inequality has been on the decline (Figure 9). Some studies attribute this to the Great Western Development Strategy (Fan, Kanbur, and Zhang 2011). Decomposition analysis shows that the contribution of between-province inequality to total inequality remained stable at about 10\% in 1990 and in 2008 (ADB 2012).

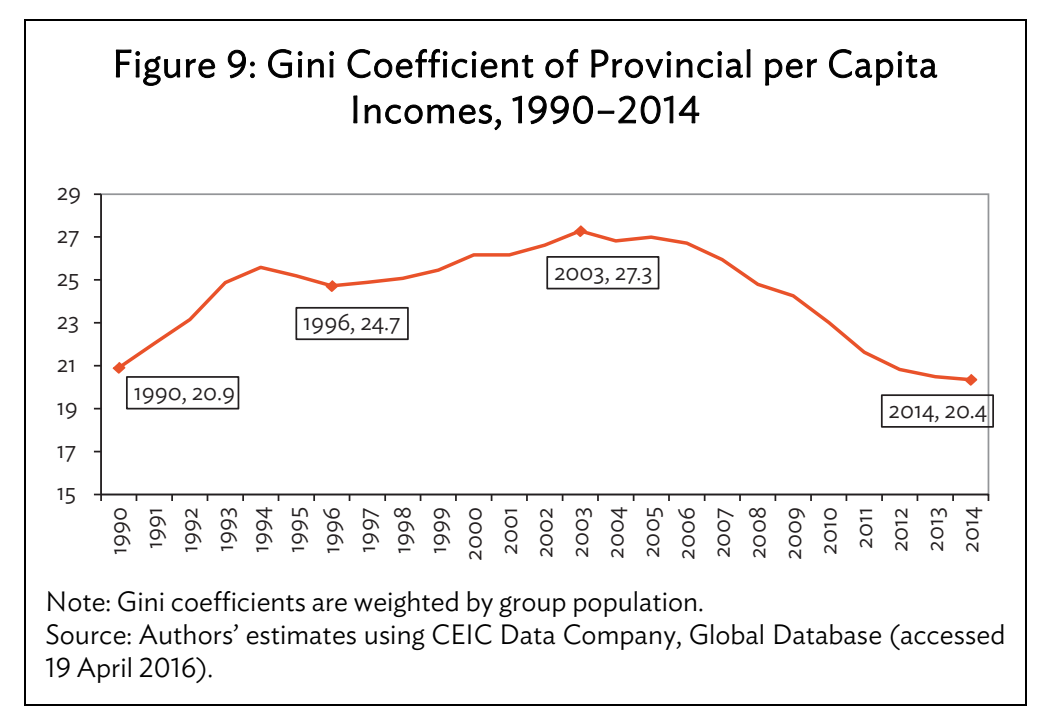




\section{Wealth Distribution}

Wealth distribution is usually more unequal than income distribution. Rising wealth inequality has likely also been a major contributor to the rising income inequality in the PRC, although it has not been studied as extensively as income inequality because of the data limitation. A recent study by Li and Wan (2015) find that wealth distribution has become more and more unequal in the PRC. For the PRC as a whole, the wealth Gini coefficient increased from 34 in 1988 to 73 in 2012 (Figure 10). For urban PRC, it increased from about 50 in the mid-1990s to 63 in 2010. For rural PRC, it increased from 31 in 1988 to 71 in 2010. A major contributing factor to the rising wealth distribution has been rising housing prices.

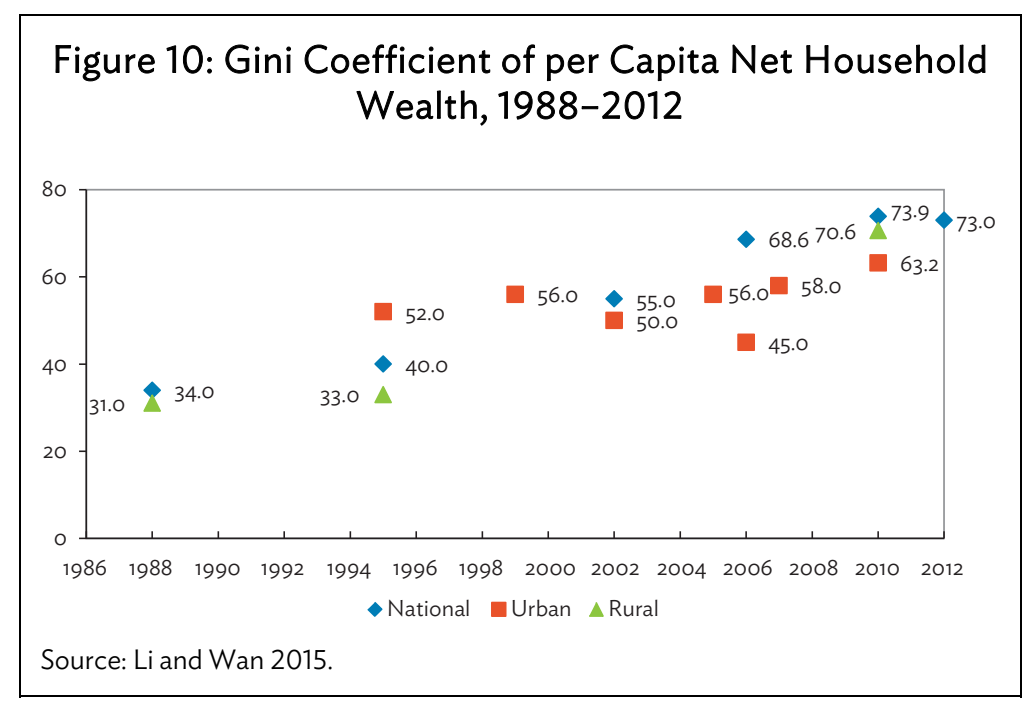

\section{CONCLUSION: HAS THE PEOPLE'S REPUBLIC OF CHINA'S INCOME INEQUALITY PEAKED?}

The previous section shows that rising skill premium, declining share of labor income and rising share of capital income, widening urban-rural income gap and regional inequality, and increasing wealth inequality have been among key drivers of rising income inequality in the PRC in recent decades. But many of these drivers appear to have reversed their directions more recently. Empirical data show that, in recent years, skill premium has declined, the share of labor income has been on the rise and capital income on the decline, and urban-urban income gaps and regional inequality have fallen, and these may have been underlying factors contributing to the decline in the PRC's overall income inequality as measured by the Gini coefficient since 2008.

Has the PRC's income inequality peaked, as suggested by the Kuznets hypothesis? For the following reasons, we believe that it is premature to think that the PRC's inequality has peaked.

First, much of the recent reverse of the drivers of the PRC's income inequality is policy induced. For instance, falling skill premium may have been due to the large government investment in tertiary education in recent years, as well as government measures to increase minimum wages for low-skilled workers. Falling regional inequality is partly due to the implementation of the Great Western Development Strategy since 2000. Narrowing urban-rural gaps are also partly related to the government's policy actions to promote urbanization and improve rural incomes and social protection in rural areas. While increasing labor income share may have been associated with the approaching of 
the Lewis turning point, it has also something to do with the rising minimum wages set by many provincial governments. The fact that there are still more than 200 million people working in the agriculture sector means that labor market situation could change, especially when the PRC's growth slows down. For all these reasons, policies for reducing inequality should continue if inequality is to be reduced further.

Second, inequality in wealth distribution has continued to increase in the PRC, and could be a new major source of rising income inequality in the PRC.

Third, although Kuznets hypothesized that income inequality will first increase, then peak, and then decline as a country's income level increases, empirical testing of the Kuznets hypothesis has so far yielded mixed results. Recent experiences of the developed countries-many of which saw rising inequality in the last 2-3 decades-have put another shadow over the validity of the Kuznets hypothesis. More importantly, one of the underlying factors for the inverted- $U$ hypothesis is that as a country becomes more advanced, the rising middle class will demand for greater income redistribution through taxation and public spending (Kuznets 1955). This suggests the importance of public policy in containing and reducing income inequality.

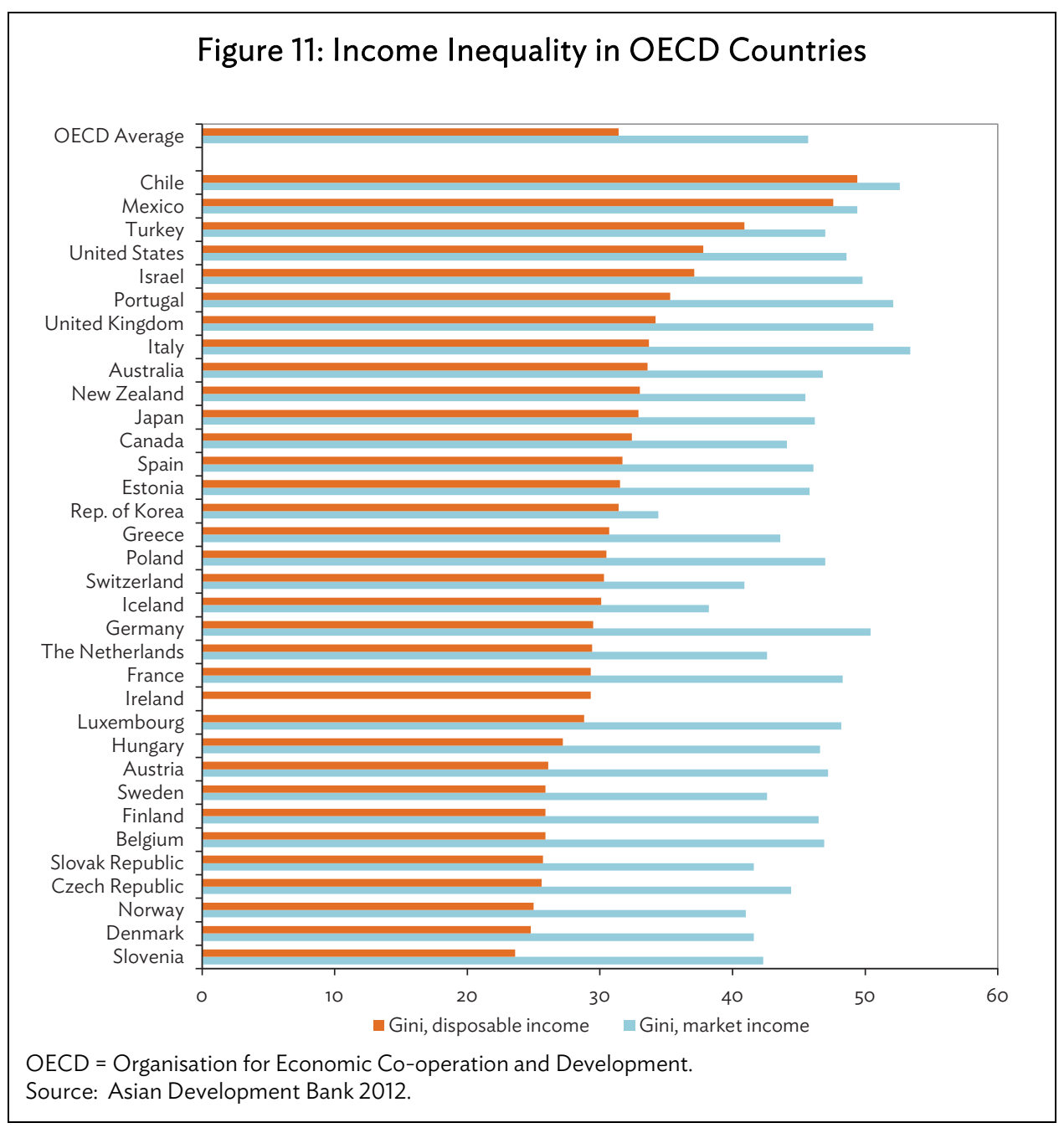


In most OECD countries, while posttax and posttransfer Gini coefficients that are based in per capita disposable income are low, in the range of 25-35, their pretax and pretransfer Gini coefficients that are based in per capita market income are not low, mostly in the range of 40-50, about one-third higher (Figure 11). The PRC's current Gini coefficient of per capita household disposable income, as shown in Figure 1, is within this range. Li, Wan, and Zhuang (2014) and Zhan and Li (2016) show that income redistribution plays a very limited role in reducing income inequality in the PRC. In 2009, the pretax urban Gini coefficient was 34.7 and posttax Gini coefficient was 33.5, only slightly lower; in 2013, the two were 38.5 and 37.3, respectively (Table 2).

The limited role of personal income taxes in reducing income inequality in the PRC is consistent with the fact that, as recently as 2013, the country's total personal income tax revenue only amounted to about $1.5 \%$ of gross domestic product. This suggests that the future path of the PRC's income inequality may not be one directional, and reducing income inequality significantly may require personal income tax and transfers to play a greater role over time.

Table 2: Pretax and Posttax Urban Gini Coefficient, People's Republic of China

\begin{tabular}{lcc}
\hline Year & Pretax Gini & Posttax Gini \\
\hline 1997 & 30.1 & 29.6 \\
2002 & 32.5 & 31.8 \\
2005 & 35.2 & 34.2 \\
2008 & 36.3 & 35.1 \\
2009 & 34.7 & 33.5 \\
2013 & 38.5 & 37.3 \\
\hline
\end{tabular}

Sources: Li, Wan, and Zhuang 2014; Zhan and Li 2016.

In sum, the recent decline in income inequality in the PRC as measured by the Gini coefficient is encouraging. But part of the decline is policy induced, and there is no guarantee that the decline will continue in the absence of these policies. It is therefore important for the PRC to continue its efforts in reducing income inequality by creating more opportunities for a wider section of the population and making greater use of fiscal policy to equalize access to opportunities, including greater public spending on education, health care, and social protection, especially for rural population; and more effective and fairer personal income taxes. The government has recently indicated that personal income tax reform will be a priority under its 13th Five-Year Plan during 2016-2020 (China Daily 2016). 


\section{REFERENCES}

Asian Development Bank (ADB). 2012. Asian Development Outlook 2012: Confronting Rising Inequality. Manila.

Bai, C., and Z. Qian. 2009. Factor Income Distribution: The Story behind the Statistics. Tsinghua, People's Republic of China: Tsinghua University.

Chan, W. K. 2015. Higher Education and Graduate Employment in China: Challenges for Sustainable Development. Higher Education Policy. 28 (1). pp. 35-53.

China Daily. 2016. China Clarifies New Five-Year Plan at Key Forum. 22 March. http://www.chinadaily .com.cn/china/2016-03/22/content_24002667.htm

China National Bureau of Statistics (CNBS). Various years. China Statistical Yearbook. http://www.stats.gov.cn/ (accessed 16 April 2016).

2015. China's Economic Realized a Stable Growth in 2014 under New Normal. Press Release. 20 January. http://www.stats.gov.cn/tjsj/zxfb/201502/t20150211_682459.html (accessed 16 April 2016).

2016. China's Economy Realized a Moderate but Stable and Sound Growth in 2015. Press Release. 19 January. http://www.stats.gov.cn/tjsj/zxfb/201601/t20160119_1306083.html (accessed 16 April 2016).

Deng, Q., and Li, S. 2009. What Lies behind Rising Earnings Inequality in Urban China? RegressionBased Decompositions. Cesifo Economic Studies. 55 (3-4). pp. 598-623.

Fan, S., R. Kanbur, and X. Zhang. 2011. China's Regional Disparities: Experience and Policy. Review of Development Finance. 1 (1). pp. 47-56.

Gustafsson, B., S. Li, and T. Sicular. 2010. Inequality and Public Policy in China. New York: Cambridge University Press.

Hussain, A., and J. Zhuang. 2000. Evolution of Inter-provincial Inequality in China, 1952-1996. In T. Atkinson, H. Glennerster, and N. Stern, eds. Putting Economics to Work: Volume in Honor of Michio Morishima. STICERD Occasional Paper No. 22. London: Suntory and Toyota International Centres for Economics and Related Disciplines.

Kanbur, R., and X. Zhang. 1999. Which Regional Inequality: Rural-Urban or Coast-Inland? An Application to China. Journal of Comparative Economics. 27 (4). pp. 686-701.

Knight, J., Q. Deng, and S. Li. 2011. The Puzzle of Migrant Labour Shortage and Rural Labour Surplus in China. China Economic Review. 22 (4). pp. 585-600.

2016. China's Expansion of Higher Education: The Labour Market Consequences of a Supply Shock. CSAE Working Paper WPS/2016-04. Oxford: Centre for the Study of African Economies. 
Knight, J., and L. Song. 2003. Increasing Urban Wage Inequality in China. Economics of Transition. 11 (4). pp. 597-619.

Krugman, P. 2008. The Increasing Returns Revolution in Trade and Geography. http://www.nobelprize.org/nobel_prizes/economics/laureates/2008/krugman_lecture.pdf

Kuznets, S. 1955. Economic Growth and Income Inequality. American Economic Review. 45 (1). pp. 128.

Lerman, R. I., and S. Yitzhaki. 1985. Income Inequality Effects by Income Source: A New Approach and Applications to the United States. The Review of Economics and Statistics. 67 (1). pp. 151-56.

Lewis, W. A. 1954. Economic Development with Unlimited Supply of Labour. The Manchester School. 22 (2). pp. 139-91.

Li, S., and C. Lin. 2015. The Impacts of the Minimum Wage Policy in China. CIID Working Paper Series. No. 35. http://www.ciidbnu.org/news/201511/20151107150350706.html

Li, S., C. Luo, and T. Sicular. 2011. Overview: Income Inequality in China: The Intergenerational Dimension. CIBC Centre for Human Capital and Productivity Working Paper No. 201113. Ontario: University of Western Ontario.

Li, S., H. Sato, and T. Sicular, eds. 2013. Rising Income Inequality in China. Cambridge: Cambridge University Press.

Li, S., G. Wan, and J. Zhuang. 2014. Income Inequality and Redistributive Policy in the People's Republic of China. In R. Kanbur, C. Rhee, and J. Zhuang, eds. Inequality in Asia and the Pacific. Manila: ADB and New York: Routledge.

Li, S., and H. Wan. 2015. Evolution of Wealth Inequality in China. China Economic Journal. 8 (3). pp. 264-87.

Lin, T., J. Zhuang, D. Yarcia, and F. Lin. 2010. Decomposing Income Inequality: People's Republic of China, 1990-2005. In J. Zhuang, ed. Poverty, Inequality, and Inclusive Growth in Asia: Measurement, Policy Issues, and Country Studies. Manila: ADB and London: Anthem Press.

Liu, L. 2009. Skill Premium and Wage Differences: The Case of China. Conference paper for the Second International Symposium on Knowledge Acquisition and Modeling.

Organisation for Economic Co-operation and Development (OECD). OECD.Stat Extract. http://stats.oecd.org/index.aspx

Piketty, T. 2014. Capital in the Twenty-First Century. Cambridge, MA and London, England: The Belknap Press of Harvard University Press.

Ravallion, M., and S. Chen. 2007. China's (Uneven) Progress against Poverty. Journal of Development Economics. 82 (1). pp. 1-42.

Rozelle, S. 1994. Rural Industrialization and Increasing Inequality: Emerging Patterns in China's 
Reforming Economy. Journal of Comparative Economics. 19 (3). pp. 362-91.

Sicular, T., Y. Ximing, B. Gustafsson, and S. Li. 2008. The Urban-Rural Income Gap and Income Inequality in China. In G. Wan, ed. Understanding Inequality and Poverty in China: Methods and Applications. New York: Palgrave Macmillan.

Tsui, K. 1993. Decomposition of China's Regional Inequality. Journal of Comparative Economics. 17 (3). pp. 600-627.

UNU-WIDER. World Income Inequality database. http://www.wider.unu.edu/research/Database/ en_GB/database/

Wan, G. H., and J. Zhuang. 2015. Making Growth More Inclusive. In J. Zhuang, P. Vandenberg, and Y. Huang, eds. Managing the Middle Income Transition-Challenges Facing the People's Republic of China. UK: Edward Elgar.

World Bank. World Development Indicators. http://data.worldbank.org/

2012. Is Higher Education Meeting Its Promises? Putting Higher Education to Work: Skills and Research for Growth in East Asia. World Bank East Asia and Pacific Regional Report. Washington, DC.

Zhan, P., and S. Li. 2016. The Impact of Personal Income Tax on China's Income Distribution. CIID Working Paper Series.

Zhang, Y., Y. Zhao, A. Park, and X. Song. 2005. Economic Returns to Schooling in Urban China, 1998 to 2001. Journal of Comparative Economics. 33 (4). pp. 730-52.

Zhuang, J., R. Kanbur, and C. Rhee. 2014 What Drives Asia's Rising Inequality? In R. Kanbur, C. Rhee, and J. Zhuang, eds. Inequality in Asia and the Pacific, Manila: ADB and New York: Routledge. 


\section{Understanding Recent Trends in Income Inequality in the People's Republic of China}

This paper examines underlying factors that could explain the decline in income inequality in the People's Republic of China (PRC) since 2008 and inquires whether the decline indicates the PRC's income inequality has peaked following the Kuznets hypothesis. The paper first identifies four key drivers of rising income inequality in the PRC since the mid-1980s: rising skill premium, declining share of labor income, increasing spatial inequality, and widening inequality in the distribution of wealth. It then provides evidence that the reversal of these drivers, with the exception of wealth inequality, could partly explain the decline in income inequality since 2008. The paper argues that since part of the reversal of these drivers is policy induced, it is important that the policy actions continue for income inequality to decline further. The paper further argues that a critical factor underlying the Kuznets hypothesis is that taxation and transfers play a bigger role in income redistribution as a country becomes more developed, while their role is still limited in the PRC, income inequality in the country is likely to stay high before personal income tax plays a bigger role.

\section{About the Asian Development Bank}

ADB's vision is an Asia and Pacific region free of poverty. Its mission is to help its developing member countries reduce poverty and improve the quality of life of their people. Despite the region's many successes, it remains home to the majority of the world's poor. $A D B$ is committed to reducing poverty through inclusive economic growth, environmentally sustainable growth, and regional integration.

Based in Manila, ADB is owned by 67 members, including 48 from the region. Its main instruments for helping its developing member countries are policy dialogue, loans, equity investments, guarantees, grants, and technical assistance. 